\begin{tabular}{|l|l|l|l|l|l|}
\hline J. Tek. Ling & Vol. 13 & No. 2 & Hal. 151 - 158 & Jakarta, Mei 2012 & ISSN 1441-318X \\
\hline
\end{tabular}

\title{
EFEKTIVITAS JUMLAH RUMPUN TANAMAN ECENG GONDOK (Eichhornia crassipes (Mart) Solm) DALAM PENGENDALIAN LIMBAH CAIR DOMESTIK
}

\author{
Yusriani Sapta Dewi \\ Program Studi Teknik Lingkungan Fakultas Teknik Universitas Satya Negara Indonesia \\ Email : yenisapta@yahoo.co.id
}

\begin{abstract}
Abstrak
Beberapa tanaman air dapat menyerap senyawa organik, anorganik dan bahan kimia lainnya yang terkandung dalam air limbah domestik. Eceng gondok (Eichhornia crassipes (Mart.) Solms), yang dikenal sebagai gulma air dapat digunakan untuk mengendalikan pencemaran air akibat limbah domestik. Tujuan penelitian ini adalah mengetahui efektivitas jumlah rumpun eceng gondok (E. crassipes) dalam mengendalikan pencemaran air oleh limbah domestik. Metode penelitian dilakukan dengan eksperimen Rancangan Acak Kelompok Lengkap. Analisis data menggunakan formula efektivitas dan Rancangan Acak Kelompok Lengkap. Hasil penelitian menunjukkan bahwa perlakuan limbah cair domestik dengan eceng gondok (E. crasssipes) pada hari ke 14 efektif secara nyata menurunkan suhu, $\mathrm{pH}, \mathrm{BOD}, \mathrm{COD}$, zat teroksidasi dan zat tersuspensi limbah cair domestik. Efektivitas penurunan tertinggi pada perlakuan dengan 3 rumpun tanaman eceng gondok; suhu turun $18,3 \%$; BOD turun $64,6 \%$, COD turun $18,2 \%$, zat teroksidasi turun $60,3 \%$ dan zat tersuspensi turun $97,7 \%$ dari nilai kontrol.
\end{abstract}

Kata kunci: air limbah domestik, eceng gondok (E. crassipes), efektivitas, jumlah rumpun tanaman.

\begin{abstract}
Some aquatic plants can absorb organic compounds, anorganic and other chemicals contained in domestic wastewater. Eceng gondok (Eichhornia crassipes (Mart.) Solms), known as water weeds and useless plants that can be used to solve the water pollution control domestic water. The research objective was to determine the effectiveness of the group of eceng gondok (E. crassipes) in the control of domestic wastewater. Methods of research done of experiments designed to study Randomized Complete Group. Analysis of the data used is to use formulas and using the Random Group Design Complete. The conclusion of this study is that the domestic wastewater treatment with eceng gondok (E. crassipes) on 14 days significantly decreased the effective temperature, $\mathrm{pH}, B O D$, $C O D$, suspended matter is oxidized and the substance of domestic wastewater. The highest decrease in the effectiveness of treatment with thee group of eceng gondok ( $E$. crassipes.); temperature 18,3\%, BOD 64,6\%, COD 18,2 \%, oxidized substance 60,3 $\%$ and suspended matter $97,7 \%$ from the value of the control.
\end{abstract}

Key words : eceng gondok (E. crassipes), domestic wastewater,the group of plants, the effectiveness. 


\section{PENDAHULUAN}

\subsection{Latar Belakang Masalah}

Sebagai komponen lingkungan hidup, air mempengaruhi dan dipengaruhi oleh komponen lainnya. Jumlah penduduk yang makin meningkat dan tingkat kebutuhan yang makin beragam, menggeser air yang semula tidak mempunyai nilai ekonomis, makin langka dari segi kualitas maupun kuantitas. Penyediaan air bersih di Indonesia masih menjadi masalah sampai saat ini, meskipun Indonesia memiliki $6 \%$ dari persediaan air dunia (21\% persediaan air di Asia Pasifik).

Peningkatan kebutuhan yang makin beragam seiring dengan perkembangan teknologi yang pesat dan ditandai antara lain dengan tumbuhnya berbagai industri, kegiatan pembangunan dan perubahan gaya hidup. Tidak dipungkiri bahwa selain manfaat yang diperoleh, bahan buangan berupa limbah industri maupun domestik ternyata menimbulkan gangguan terhadap kehidupan sekitarnya. Tanpa pengolahan, limbah limbah domestik dan limbah industri akan menyebabkan peningkatan beban pencemar pada badan air. Tingginya tingkat pencemaran akan menyebabkan badan air kehilangan kemampuan untuk melakukan perbaikan alami.

Hasil penelitian terdahulu menunjukkan bahwa tumbuhan air tertentu dapat menyerap senyawa organik, anorganik dan senyawa kimia lain yang terkandung dalam perairan. Sudah banyak dicoba cara penjernihan air yang telah tercemar melalui biofiltrasi dengan menggunakan tumbuhan air. Salah satu di antaranya adalah eceng gondok, ( $E$. crasssipes), yang selama ini dikenal sebagai gulma air yang merugikan. Eceng gondok (E. crassipes) pertama kali ditemukan oleh Carl Friedrich Philipp von Martius ahli botani berkebangsaan Jerman pada tahun $1824 \mathrm{di}$ Sungai Amazon Brasil' ${ }^{1}$.

Eceng gondok (E.crassipes) adalah salah satu jenis tumbuhan air mengapung; biasanya tumbuh di kolam-kolam dangkal, tanah basah dan rawa, aliran air yang lambat, danau, tempat penampungan air dan sungai. Di beberapa daerah Indonesia, nama eceng gondok mempunyai nama lain di antaranya di daerah di Manado dikenal dengan nama Tumpe, di Palembang dikenal dengan nama Kelipuk, di Lampung dikenal dengan nama Ringgak, di Dayak dikenal dengan nama llung-ilung ${ }^{2)}$.

\subsection{Tujuan Penelitian}

Penelitian ini dilakukan untuk mengetahui efektivitas jumlah rumpun tanaman eceng gondok (E. crasssipes) dalam pengendalian limbah domestik. Hasil penelitian diharapkan dapat menjadi sumbangan pemikiran dalam menyelesaikan pencemaran badan air oleh limbah domestik.

\section{METODOLOGI}

Penelitian dirancang secara eksperimen Rancangan Acak Kelompok Lengkap.

\subsection{Bahan}

Eceng gondok diambil dari perairan bebas, dengan berat tanaman, jumlah daun, lebar daun dan keadaan morfologi lainnya yang sama. Sampel air limbah diambil dari pusat pembuangan air limbah terpadu (dalam penelitian ini diambil dari Balai Teknik Kesehatan Lingkungan, Jakarta).

\subsection{Alat}

Alat percobaan yang digunakan adalah ember plastik sebanyak 20 buah, filter air buangan, $\mathrm{pH}$ meter, penggaris, timbangan, kertas penghisap, thermometer, alat-alat laboratorium.

\subsection{Cara Penelitian}

Persiapan yang dilakukan adalah membuat saringan air untuk menyaring 
partikel-partikel kasar sampel air limbah. Eceng gondok (Eichhornia crasssipes (Mart.) Solms) yang terpilih dibersihkan dari segala kotoran dan ditanam dalam air sumur selama 7 (tujuh) hari untuk mengetahui volume air limbah yang dibutuhkan dalam percobaan. Setelah melalui penyaringan kasar air limbah diisikan dalam 20 ember plastik masingmasing sebanyak 1,5 liter. Desain perlakuan ini adalah 4x5; yang artinya ada 4 perlakuan dengan 5 kali ulangan. Perlakuan A adalah kontrol, di mana ember tidak ditanami eceng gondok; perlakukan $\mathrm{B}$, ember ditanami 1 tanaman eceng gondok; perlakuan C, ember ditanami 2 tanaman eceng gondok; perlakuan $\mathrm{D}$, ember ditanami 3 tanaman eceng gondok. Waktu percobaan selama 14 (empat belas hari).

\subsection{Metode Pengukuran Parameter}

Tabel 1. Metode pengukuran parameter

\begin{tabular}{|l|l|}
\hline \multicolumn{1}{|c|}{ Parameter } & \multicolumn{1}{|c|}{ Metode/alat } \\
\hline Suhu & Kalorimetrik/Thermometer \\
\hline $\mathrm{pH}$ & Potensiometrik/pH meter \\
\hline BOD & $\begin{array}{l}\text { Winkler alkali ioda azida/DO } \\
\text { meter }\end{array}$ \\
\hline COD & $\begin{array}{l}\text { Spektrofotometrik/spectropho- } \\
\text { tometer }\end{array}$ \\
\hline z.suspensi & Gravimetri/TDS meter \\
\hline z.teroksida-si & $\begin{array}{l}\text { Spektrofotometrik/spectropho- } \\
\text { tometer }\end{array}$ \\
\hline Luas daun & Gravimetri \\
\hline Panjang akar & Milimeter paper \\
\hline
\end{tabular}

\subsection{Analisis Penelitian}

Nilai efektivitas dinyatakan dalam persen $(\%)$ dengan formulasi umum sebagai berikut :

$$
\mathrm{E}=\frac{\mathrm{Co}-\mathrm{Ci}}{\mathrm{Co}} \times 100 \%
$$

di mana

$E=$ efektivitas penurunan parameter; $\mathrm{Co}=$ konsentrasi sebelum perlakuan dan
$\mathrm{Ci}=$ konsentrasi sesudah perlakuan.

Analisis Rancangan Acak Kelompok

Lengkap :

$$
Y_{i j}=\mu\left|T_{i}\right| \beta_{j} \mid \varepsilon_{i j}
$$

di mana $Y_{i j}=$ pengamatan pada perlakuan ke-i dan kelompok ke-j; $\mu=$ mean populasi; $\tau_{i}=$ pengaruh aditif dari perlakuan ke-i; $\beta_{j}=$ pengaruh aditif dari kelompok ke-j; $\varepsilon_{i j}=$ pengaruh acak dari perlakuan ke-i dan kelompok ke-j; dengan $\mathrm{i}=1,2,3, \ldots$ t dan $\mathrm{j}=$ $1,2,3 \ldots r$

\section{HASIL PENELITIAN DAN PEMBAHASAN}

\subsection{Data awal}

Hasil analisis laboratorium terhadap beberapa parameter air limbah domestik setelah dilakukan penyaringan dengan metode pasir cepat adalah $\mathrm{pH} 9,62$; BOD $321,38 \mathrm{mg} / \mathrm{l}$; COD 997,6 mg/l; zat tersuspensi $7,5 \mathrm{mg} / \mathrm{l}$ dan zat teroksidasi $18,0 \mathrm{mg} / \mathrm{l}$. Data ini dipakai sebagai data limbah kontrol. Untuk data fisik eceng gondok, rerata panjang akar $17-18 \mathrm{~cm}$; untuk luas daun 1 rumpun tanaman : $510 \mathrm{~mm} 2,2$ rumpun tanaman $974 \mathrm{~mm}^{2}$ dan 3 rumpun tanaman $1187 \mathrm{~mm}^{2}$.

\subsection{Data Akhir}

\subsubsection{Suhu}

Hasil ini menunjukkan bahwa suhu air dari perlakuan dengan eceng gondok (E.crasssipes) berbeda nyata dengan kontrol. Hal ini diperkuat dengan sidik ragam dan uji beda nyata (LSD) pada taraf uji $5 \%$. Kondisi ini menunjukkan bahwa adanya eceng gondok (E.crasssipes) berpengaruh terhadap suhu air. Berdasarkan nilai rerata suhu air, ternyata suhu tertinggi limbah adalah pada perlakuan kontrol $\left(37,8^{\circ} \mathrm{C}\right)$, sedangkan suhu terendah pada perlakuan dengan 3 tanaman eceng gondok 
(E. crasssipes) yaitu $30,9^{\circ} \mathrm{C}$. Efektivitas penurunan suhu pada perlakuan 3 rumpun tanaman eceng gondok sebesar $18,3 \%$ dari nilai kontrol. Hal ini menunjukkan bahwa semakin banyak jumlah rumpun tanaman, makin menghambat naiknya suhu. Pengaruh naungan berdasarkan rerata luas permukaan daun dengan rerata suhu air, menunjukkan bahwa semakin luas permukaan daun yang menutupi permukaan air, suhu air makin rendah. Dapat disimpulkan bahwa adanya eceng gondok dapat menghambat naiknya suhu.

Tabel 1. Rerata suhu air limbah hasil perlakuan dengan eceng gondok selama 14 hari

\begin{tabular}{|l|l|l|l|}
\hline No. & Perlakuan & $\begin{array}{c}\text { Luas } \\
\text { permukaan } \\
\text { daun }\left(\mathrm{mm}^{2}\right)\end{array}$ & \multicolumn{1}{|c|}{$\begin{array}{c}\text { Rerata } \\
\text { Suhu }\left({ }^{\circ} \mathrm{C}\right)\end{array}$} \\
\hline 1. & Kontrol & & $37,8 \mathrm{a}$ \\
\hline 2. & 1 tanaman & 532,96 & $34,4 \mathrm{~b}$ \\
\hline 3. & 2 tanaman & 981,25 & $32,3 \mathrm{c}$ \\
\hline 4. & 3 tanaman & 1195,21 & $30,9 \mathrm{~d}$ \\
\hline
\end{tabular}

$F_{\text {hit }}(95,4)>F_{\text {tab }}(3,24) ; \operatorname{LSD}_{(0,05)}=0,948$;

$\operatorname{LSD}_{(0,01)}=1,306$

Nilai rerata yang diikuti huruf yang sama,tidak beda nyata pada taraf

uji beda terkecil (LSD) taraf $5 \%$

${ }^{\circ} \mathrm{C}$

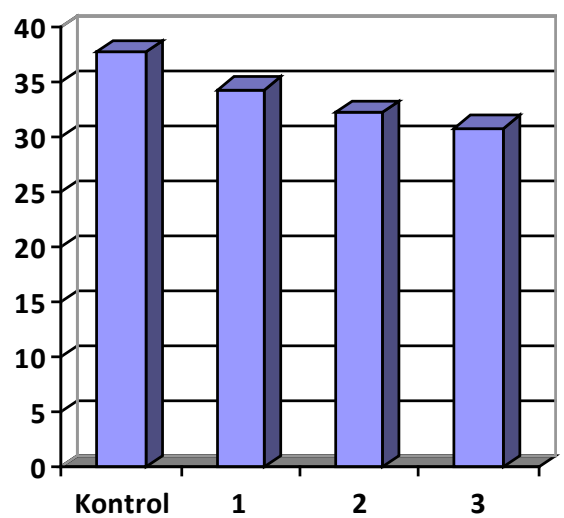

Gambar 1. Rerata suhu setelah perlakuan 14 hari

\subsubsection{Derajat keasaman $(\mathrm{pH})$}

Tabel 2. Nilai rerata $\mathrm{pH}$ hasil perlakuan dengan eceng gondok selama 14 hari

\begin{tabular}{|l|l|l|}
\hline No. & Perlakuan & Rerata \\
\hline 1. & Kontrol & $9,62 \mathrm{a}$ \\
\hline 2. & 1 tumbuhan & $7,60 \mathrm{~b}$ \\
\hline 3. & 2 tumbuhan & $7,38 \mathrm{c}$ \\
\hline 4. & 3 tumbuhan & $7,28 \mathrm{~d}$ \\
\hline
\end{tabular}

$F_{\text {hit }}(223,3)>F_{\text {tab }}(3,24) ; \operatorname{LSD}_{(0,05)}=0,222$; $\operatorname{LSD}_{(0,01)}=0,0306$.

Nilai rerata yang diikuti huruf yang sama,tidak beda nyata pada taraf uji beda terkecil (LSD) taraf $5 \%$

Hasil penelitian menunjukkan bahwa $\mathrm{pH}$ air dari perlakuan dengan eceng gondok (E. crasssipes) berbeda nyata dengan kontrol. Hal ini diperkuat dengan sidik ragam dan uji LSD pada taraf nyata 5\%. Dari hasil ini dapat disimpulkan bahwa perlakuan dengan eceng gondok (E. crasssipes) berpengaruh terhadap $\mathrm{pH}$ air. Perbedaan rerata $\mathrm{pH}$ air antar perlakuan kemungkinan disebabkan oleh pernapasan akar yang terjadi di dalam air. Dalam pernapasan akar, akan diserap $\mathrm{O}_{2}$ dan dikeluarkan $\mathrm{CO}_{2}$. Reaksi antara $\mathrm{CO}_{2}$ dengan unsur-unsur yang ada dalam air dapat mengakibatkan keadaan asam. Kemungkinan semakin banyaknya $\mathrm{CO}_{2}$ dalam air menyebabkan $\mathrm{pH}$ air berangsur-angsur mendekati $\mathrm{pH}$ standar (7). Efektivitas penurunan $\mathrm{pH}$ dengan 1 tanaman sebesar $21 \%$; perlakuan 2 tanaman $\mathrm{pH}$ turun $23 \%$ dan perlakuan 3 tanaman $\mathrm{pH}$ turun sebesar $24 \%$ dari nilai kontrol. Hal ini diperkuat oleh pendapat Suardana bahwa perlakuan penutupan eceng gondok sebanyak $30 \%, 60 \%$ dan $90 \%$ pada hari ke 7,14 dan 21 pada pengolahan biologis limbah rumah pemotongan hewan, menunjukkan penurunan $\mathrm{pH}$ secara nyata sampai $24,30 \%$ dari nilai awal ${ }^{3)}$. 
$\mathrm{pH}$

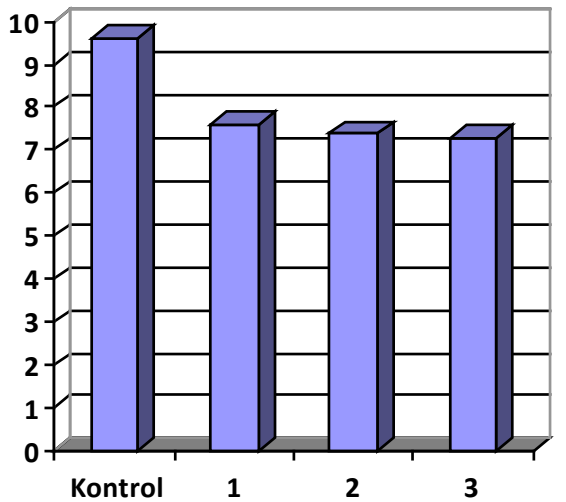

Gambar 2. Rerata pH setelah perlakuan 14 hari

\subsubsection{Biochemical Oxygen Demand (BOD), Chemical Oxygen Demand (COD)}

nitrogen organik, yaitu dalam bahan-bahan berprotein yang berasal antara lain dari limbah domestik. Dekomposisi oleh bakteri merubahnya menjadi ammonia. Bakteri dapat mengoksidasi ammonia menjadi nitrit dan nitrat dalam lingkungan aerobik. Kedua parameter ini dalam perairan sangat tergantung pada ketersediaan oksigen terlarut, sumber dan tipe bahan organik, tipe dan kondisi perairan ${ }^{5}$. Nitrat merupakan senyawa terpenting karena dalam senyawa ini lebih mudah diserap oleh tanaman air dan dapat digunakan dalam proses fotosintesis 6). Jumlah rumpun tanaman mempengaruhi proses fotosintesis dan pemanfaatan nitrat serta turunnya nilai BOD perairan. Dapat dikatakan bahwa banyaknya rumpun eceng gondok dalam perlakuan berpengaruh

Tabel 3. Nilai rerata BOD,COD, Panjang Akar, Luas Daun perlakuan eceng gondok selama 14 hari

\begin{tabular}{|l|l|r|r|r|r|}
\hline No. & Perlakuan & Rerata BOD $(\mathrm{mg} / \mathrm{l})$ & Rerata COD $(\mathrm{mg} / \mathrm{l})$ & $\begin{array}{l}\text { Rerata panjang } \\
\text { akar }(\mathrm{cm})\end{array}$ & $\begin{array}{l}\text { Rerata luas daun } \\
(\mathrm{mm} 2)\end{array}$ \\
\hline 1. & Kontrol & $472,17 \mathrm{a}$ & $919,36 \mathrm{a}$ & - & - \\
\hline 2. & 1 tumbuhan & $499,58 \mathrm{ab}$ & $813,36 \mathrm{a}$ & 22,46 & 532,96 \\
\hline 3. & 2 tumbuhan & $316,07 \mathrm{bc}$ & $808,76 \mathrm{a}$ & 23,60 & 981,25 \\
\hline 4. & 3 tumbuhan & $167,29 \mathrm{c}$ & $752,56 \mathrm{a}$ & 25,05 & 1195,21 \\
\hline
\end{tabular}

Nilai rerata yang diikuti huruf yang sama,tidak beda nyata pada taraf uji beda terkecil (LSD) taraf $5 \%$

Hasil penelitian menunjukkan bahwa BOD dari perlakuan eceng gondok ( $E$. crasssipes) berbeda nyata dengan kontrol. Jadi perlakuan dengan eceng gondok ( $E$. crasssipes) berpengaruh terhadap nilai BOD. Hasil sidik ragam dan uji beda nyata terkecil (LSD) pada taraf nyata $5 \%$ untuk masing-masing perlakuan menunjukkan bahwa antara perlakuan 1 tumbuhan dan perlakuan 2 tumbuhan tidak beda nyata dengan kontrol; sedang antara 3 perlakuan tumbuhan berbeda nyata dengan kontrol. BOD merupakan parameter untuk mengetahui kebutuhan oksigen biologis untuk memecah bahan buangan di dalam air oleh mikroorganisme ${ }^{4)}$. Sebagian besar dari nitrogen total dalam air dapat terikat sebagai terhadap nilai BODnya.

Nilai rerata perlakuan 2 tumbuhan dan perlakuan 3 tumbuhan menunjukkan bahwa BOD mengalami penurunan. Efektivitas penurunan BOD dengan perlakuan 2 tanaman sebesar $33 \%$; sedangkan perlakuan dengan 3 rumpun tanaman sebesar $64,6 \%$ dari kontrol. Beberapa penelitian terdahulu menyatakan bahwa eceng gondok mempunyai kemampuan menyerap unsur hara, senyawa organik dan kimia lain dari air limbah dalam jumlah besar. Penelitian Suardana memperkuat, bahwa perlakuan dengan penutupan $90 \%$ eceng gondok, menyebabkan penurunan nilai BOD sampai $55,50 \%$ dari nilai awal ${ }^{3)}$. 


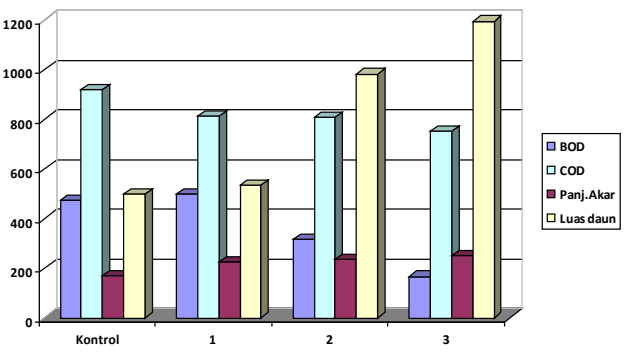

Gambar 3. Rerata BOD,COD, panjang akar dan luas daun setelah perlakuan 14 hari

Luas permukaan daun dan panjang akar mempengaruhi transpirasi yang kemudian berhubungan dengan besarnya penyerapan, yang mempengaruhi nilai BODnya. Hal ini berarti adanya eceng gondok (E. crasssipes) dalam suatu perairan akan mempengaruhi bahan organik di perairan tersebut. Terdapat respon fisiologis daun, tangkai daun dan akar eceng gondok terhadap perairan tercemar. Respon ini juga akan mempengaruhi transpirasi dan besarnya penyerapan ${ }^{7)}$. Penurunan BOD yang terjadi pada perlakuan 3 tumbuhan lebih besar dibandingkan dengan perlakuan lain; kemungkinan karena sebagian dari senyawa organik telah diuraikan menjadi senyawa lain yang lebih sederhana dan kemudian diserap oleh tumbuhan untuk proses metabolismenya.

Hasil penelitian COD menunjukkan bahwa perlakuan dengan eceng gondok (E. crasssipes), tidak berbeda nyata dengan kontrol; namun apabila dilihat dari perbedaan rerata COD setelah perlakuan menunjukkan penurunan dibandingkan dengan kontrol. Efektivitas penurunan COD dengan perlakuan 1 rumpun tanaman, 2 rumpun tanaman dan 3 rumpun tanaman secara berturut-turut adalah $11,5 \%, 7,7 \%$, dan $18,2 \%$. Hal ini berarti bahwa adanya eceng gondok (E.crasssipes), menunjukkan kecenderungan menurunkan nilai COD.

\subsubsection{Zat Teroksidasi dan Zat Tersuspensi}

Hasil penelitian zat teroksidasi menunjukkan bahwa perlakuan dengan eceng gondok ( $E$. crasssipes) berbeda dengan kontrol. Hal ini menunjukkan bahwa adanya eceng gondok ( $E$. crasssipes) berpengaruh terhadap nilai zat teroksidasinya. Perbedaan rerata perlakuan kemungkinan disebabkan adanya penyerapan oleh eceng gondok ( $E$. crasssipes) yang dipengaruhi panjang akar dan luas permukaan daun. Berdasarkan hasil pengamatan menunjukkan semakin panjang akar dan semakin luas permukaan daunnya, makin turun zat yang teroksidasi. Efektivitas penurunan berturut-turut dengan perlakuan 1 rumpun tanaman, 2 rumpun tanaman dan 3 rumpun tanaman adalah 32,6 $\%, 57,1 \%$ dan $60,3 \%$.

Limbah atau bahan buangan yang tidak dapat larut sempurna akan mengendap ke dasar badan air; sedangkan yang dapat larut sebagian akan menjadi koloid. Endapan sebelum mengendap ke dasar badan air akan melayang bersama koloid (yang disebut zat tersuspensi) dan menghalangi masuknya sinar matahari ke lapisan air; padahal sinar matahari sangat diperlukan oleh mikroorganisme untuk melakukan proses fotosintesis. Karena tidak

Tabel 4. Nilai zat teroksidasi dan zat tersuspensi hasil perlakuan dengan eceng gondok selama 14 hari

\begin{tabular}{|l|l|l|l|}
\hline No. & Perlakuan & Rerata Zat Teroksidasi $(\mathrm{mg} / \mathrm{l})$ & Rerata Zat Tersuspensi $(\mathrm{mg} / \mathrm{l})$ \\
\hline 1. & Kontrol & $116,29 \mathrm{a}$ & $17,1 \mathrm{a}$ \\
\hline 2. & 1 tumbuhan & $78,37 \mathrm{a}$ & $12,5 \mathrm{a}$ \\
\hline 3. & 2 tumbuhan & $49,93 \mathrm{a}$ & $1,4 \mathrm{bc}$ \\
\hline 4. & 3 tumbuhan & $46,14 \mathrm{a}$ & $0,4 \mathrm{bc}$ \\
\hline
\end{tabular}

Nilai rerata yang diikuti huruf yang sama,tidak beda nyata pada taraf uji beda terkecil (LSD) taraf $5 \%$ 
ada sinar matahari maka proses fotosintesia tidak dapat berlangsung, akibatnya kehidupan mikroorganisme menjadi terganggu. Apabila zat tersuspensi berasal dari limbah organik, maka mikroorganisme dengan bantuan oksigen yang terlarut dalam air akan melakukan degradasi bahan organik tersebut menjadi nitrat dan nitrit ${ }^{4)}$. Hasil penelitian pada zat tersuspensi menunjukkan bahwa perlakuan dengan eceng gondok (E. crasssipes) berbeda nyata dengan kontrol. Jadi perlakuan dengan eceng gondok (E. crasssipes) berpengaruh terhadap nilai zat tersuspensinya. Hasil sidik ragam dan uji beda nyata terkecil pada taraf nyata $5 \%$ untuk masing-masing perlakuan, menunjukkan bahwa perlakuan dengan 1 tumbuhan tidak beda nyata dengan kontrol. Tingginya nilai zat tersuspensi pada kontrol, kemungkinan disebabkan tidak adanya penyerapan oleh tanaman. Perbedaan perlakuan jumlah rumpun tanaman menunjukkan perbedaan penurunan pada jumlah zat tersuspensi. Efektivitas penurunan zat tersuspensi pada perlakuan 1 rumpun tanaman eceng gondok $26,9 \%$; perlakuan dengan 2 rumpun tanaman $91,8 \%$ dan perlakuan dengan 3 rumpun tanaman mencapai $97,7 \%$.

Penyerapan bahan organik terlarut juga dipengaruhi oleh luas permukaan daun atau besarnya/panjangnya akar tumbuhan. Hasil pengamatan menunjukkan ada perbedaan penyerapan zat tersuspensi dengan panjang akar dan luas permukaan daun. Hal ini berarti semakin banyak tanaman eceng gondok ( $E$. crassipes) terutama banyaknya daun dan panjang akar; akan semakin banyak penyerapan bahan organik terlarut di perairan. Kenyataan ini membuktikan bahwa eceng gondok (E. crassipes) mampu menurunkan tingkat pencemaran air. Penelitian Djenar dan Herawati juga menguatkan bahwa semakin banyak jumlah rumpun tanaman eceng gondok semakin banyak akar yang menyerap amoniak di dalam air tercemar tersebut ${ }^{8)}$.

\section{KESIMPULAN DAN SARAN}

\subsection{Kesimpulan}

Berdasarkan hasil pengamatan dan pembahasan dalam penelitian ini dapat disimpulkan bahwa perlakuan limbah cair domestik dengan eceng gondok (E. crasssipes) pada hari ke 14 efektif secara nyata menurunkan suhu, $\mathrm{pH}, \mathrm{BOD}, \mathrm{COD}$, zat teroksidasi dan zat tersuspensi limbah cair domestik. Efektivitas penurunan tertinggi pada perlakuan dengan 3 rumpun tanaman eceng gondok; suhu turun 18,3\%; BOD turun $64,6 \%$, COD turun $18,2 \%$, zat teroksidasi turun $60,3 \%$ dan zat tersuspensi turun $97,7 \%$ dari nilai kontrol.

\subsection{Saran}

Eceng gondok (E. crasssipes) dapat dipergunakan untuk pengendalian limbah domestik secara biologi. Namun karena mempunyai perkembangbiakan sangat cepat baik secara generatif maupun vegetatif, dapat mempercepat pendangkalan

Tabel 5. Rerata panjang akar, luas permukaan daun dan zat teroksidasi, zat tersuspensi setelah 14 hari

\begin{tabular}{|l|l|l|l|l|l|}
\hline No & Perlakuan & $\begin{array}{l}\text { Rerata Panjang } \\
\text { akar }(\mathrm{cm})\end{array}$ & $\begin{array}{c}\text { Rerata Luas } \\
\text { permukaan }(\mathrm{mm} 2)\end{array}$ & $\begin{array}{c}\text { Rerata Zat } \\
\text { teroksidasi }(\mathrm{mg} / \mathrm{l})\end{array}$ & $\begin{array}{c}\text { Rerata Zat } \\
\text { tersuspensi }(\mathrm{mg} / \mathrm{l})\end{array}$ \\
\hline 1. & Kontrol & - & - & $116,29 \mathrm{a}$ & $17,1 \mathrm{a}$ \\
\hline 2. & 1 tumbuhan & 22,46 & 532,96 & $78,37 \mathrm{a}$ & $12,5 \mathrm{a}$ \\
\hline 3. & 2 tumbuhan & 23,60 & 981,25 & $49,93 \mathrm{a}$ & $1,4 \mathrm{bc}$ \\
\hline 4. & 3 tumbuhan & 25,05 & 1195,21 & $46,14 \mathrm{a}$ & $0,4 \mathrm{bc}$ \\
\hline
\end{tabular}

Dari hasil pembahasan tersebut di atas dapat disimpulkan bahwa adanya eceng gondok (Eichhornia crasssipes (Mart.) Solms) dapat menurunkan nilai zat tersuspensi. 


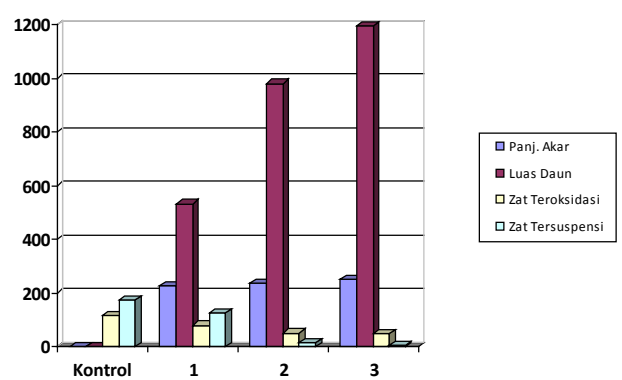

Gambar 4. Rerata Panjang akar,Luas daun, zat eruspensi dan zat teroksidasi setelah perlakuan 14 hari

perairan umum. Untuk itu perlu adanya kontrol terhadap jumlah eceng gondok (E. crasssipes).

\section{DAFTAR PUSTAKA}

1. Falah, U. Sirojul. Eceng Gondok, Gulma Sahabat Manusia? Harian Pikiran Rakyat. 28 September 2003.

2. Anon. 2008. Eceng Gondok Pembersih Polutan Logam Berat. http://id.wikipedia. org/wiki/Eceng_gondok.

3. Suardana, I.W. 2009. "Pemanfaatan Eceng Gondok (Eichhornia crassipes (Mart)Solm) Sebagai Teknik Alternatif Dalam Pengolahan Biologis Air Limbah
Asal Rumah Pemotongan Hewan (RPH) Pesanggrahan Denpasar Bali". Jurnal Berita Biologi (9)6 : 759-766.

4. Wardhana, Wisnu Arya. Dampak Pencemaran Lingkungan.Penerbit Andi. Yogyakarta

5. Uhlman. D. 1979. Hydribiology. John and Willey and Sons. Chichester.

6. Orth, H. L., and P. A. Wilderer. 1987. Waste Water Treatment for Industrial Estates in Southeast Asia Using Water Hyacinths. Wal. Sel Tech. Vol. 19. Rio, S.: 85-96.

7. Haryanti, Sri, Nintya Setiari, Rini Budi Hastuti, Endah Dwi Hastuti, dan Yulita Nurchayati. 2009. Respon Positif Fisiologi dan Anatomi Eceng Gondok (Eichhornia crassipes (Mart) Solm) Di Berbagai Perairan Tercemar. Jurnal Penelitian Sains \& Teknologi, Vol. 10, No. 1, 2009: $30-40$.

8. Djenar, Nancy Siti dan Herawati Budiastuti. 2008. Absorpsi Polutan Amoniak Di Dalam Air Tanah Dengan Memanfaatkan Tanaman Eceng Gondok (Eichhornia crassipes (Mart) Solm). Spektrum Teknologi :Vol. 15 No.2 Tahun 2008 : 97-103. 